\title{
Pengaruh Model Pembelajaran Kooperatif Learning Tipe NHT terhadap Pengetahuan Matematika
}

\author{
I Km. Jati Sugiyadnya1*, I Wyn. Wiarta², I Kt. Adnyana Putra ${ }^{3}$
}

${ }^{123}$ Universitas Pendidikan Ganesha, Indonesia

\section{A R T I C L E I N F O Article history: \\ Received 18 August 2019 Received in revised form 19 September 2019 Accepted 25 October 2019 Available online 30 November 2019 \\ Kata Kunci: \\ Numbered Head Together Pengetahuan Matematika \\ Keywords: \\ Numbered Head Together, Mathematical Knowledge}

\begin{abstract}
A B S T R A K
Penelitian ini bertujuan untuk mengetahui Pengaruh Model Pembelajaran Kooperatif Learning Tipe Numbered Head Together Terhadap Pengetahuan Matematika Kelas V SD Gugus I Gusti Ngurah Rai Denpasar Tahun Ajaran 2018/2019. Penelitian ini merupakan penelitian eksperimen semu dengan rancangan nonequivalent control group design. Populasi dalam penelitian ini adalah seluruh kelas V SD Gugus I Gusti Ngurah Rai Denpasar sebanyak 404 orang. Sampel penelitian ini kelas V SD Negeri 17 Padangsambian sebanyak 31 orang sebagai kelompok eksperimen dan kelas V A SD Negeri 18 Padangsambian sebanyak 31 orang sebagai kelompok kontrol. Metode pengumpulan data dalam penelitian ini adalah metode tes dalam bentuk tes objektif pilihan ganda biasa. Data yang diperoleh kemudian dianalisis menggunakan analisis uji-t. Berdasarkan hasil analisis terdapat perbedaan kompetensi pengetahuan matematika kelompok yang dibelajakan menggunkan model pembelajaran Kooperatif Learning Tipe Numbered Head Together kelas V SD Gugus I Gusti Ngurah Rai Denpasar tahun ajaran 2018/2019. Dapat disimpulkan terdapat pengaruh yang signifikan kompetensi pengetahuan matematika kelompok yang dibelajarkan menggunakan model pembelajaran kooperatif learning tipe Numbered Head Together dan kelompok yang dibelajarkan dengan pembelajaran konvensional kelas V SD Gugus I Gusti Ngurah Rai Denpasar tahun ajaran 2018/2019.
\end{abstract}

\section{A B S T R A C T}

This study aims to determine the Effect of Cooperative Learning Learning Model Numbered Head Together Against fifth grade of Mathematics Knowledge Elementary School I Gusti Ngurah Rai Denpasar 2018/2019 academic year. This research is a quasi-experimental study with the design of nonequivalent control group design. The population in this study were all fifth grade of SD Gugus I Gusti Ngurah Rai Denpasar amount to 404 students. The sample of this study was fifth grade of Padangsambian State Elementary School 17 as many as 31 people as the experimental group and fifth grade A Padangsambian Elementary School 18 as many as 31 people as the control group. The data collection method in this study is a test method in the form of a regular multiple choice objective test. The obtained data analyzed using t-test analysis. Based on the results of the analysis there are differences in the competency of mathematical knowledge of groups that are taxed using the Numbered Head Together Learning Cooperative learning model in fifth grade SD Gugus I Gusti Ngurah Rai Denpasar 2018/2019 academic year. Can be concluded that there is a significant effect of the mathematical knowledge competency of the group being taught using the Numbered Head Together cooperative learning model and the group taught with conventional learning fifth grade SD Gugus I Gusti Ngurah Rai Denpasar 2018/2019 academic year.

\footnotetext{
${ }^{1}$ Corresponding author.

E-mail addresses: komang.jati.sugiyadnya@undiksha.ac.id (I Km. Jati Sugiyadnya)
} 


\section{Pendahuluan}

Pendidikan merupakan salah satu wahana untuk membentuk generasi-generasi yang siap membangun bangsa, yang sangat diharapkan adanya peningkatan mutu dan kualitas. Pendidikan merupakan hal yang menjadi sorotan utama dalam masyarakat. Pendidikan memegang peranan yang sangat penting untuk membangun suatu masyarakat yang cerdas dan berkompeten. Pendidikan merupakan sarana penting untuk meningkatkan kualitas sumber daya manusia (SDM) dalam menjamin keberlangsungan pembangunan suatu bangsa. Dalam penyelenggaraan pendidikan di sekolah yang melibatkan guru sebagai pendidik dan siswa sebagai peserta didik, diwujudkan dengan adanya interaksi belajar dan proses pembelajaran. Menurut Marhadi (2014) Pendidikan merupakan sarana penting untuk meningkatkan kualitas sumber daya manusia (SDM) dalam menjamin kelangsungan pembangunan suatu bangsa. Peningkatan kualitas SDM jauh lebih mendesak untuk segera direalisasikan terutama dalam menghadapi era persaingan global. Oleh karena itu, peningkatan kualitas SDM sejak dini merupakan hal penting yang harus dipikirkan secara sungguh-sungguh.

Pembelajaran merupakan setiap kegiatan yang dirancang oleh guru untuk membantu seseorang mempelajari suatu kemampuan atau nilai yang baru dalam suatu proses yang sistematis melalui tahap rancangan, pelaksanaan, dan evaluasi. Menurut Undang-undang Nasional No. 20 Tahun 2003 menyatakan bahwa pembelajaran diartikan sebagai proses interaksi peserta didik dengan pendidik dan sumber belajar pada suatu lingkungan belajar. Sesuai dengan yang terdapat pada Undang-Undang No. 20 Tahun 2003 tentang Sistem Pendidikan Nasional, pasal 3 disebutkan tentang fungsi pendidikan nasional.

Fungsi pendidikan nasional adalah mengembangkan kemampuan dan membentuk watak serta peradaban bangsa yang bermartabat dalam rangka mencerdaskan kehidupan bangsa, bertujuan untuk berkembangnya potensi peserta didik agar menjadi manusia yang beriman dan bertakwa kepada Tuhan Yang Maha Esa, berakhlak mulia, sehat, berilmu, cakap, kreatif, mandiri, dan menjadi warga negara yang demokratis serta bertanggung jawab.

Terkait dengan upaya meningkatkan mutu pendidikan dan menciptakan sumber daya manusia yang sesuai dengan fungsi pendidikan nasional, maka berbagai inovasi telah dilakukan oleh pemerintah. Upaya yang telah dilakukan oleh pemerintah diantaranya dengan pengadaan sarana dan prasarana belajar, model pembelajaran yang inovatif dalam proses pembelajaran. Selain itu, dalam proses pembelajaran diperlukan juga dukungan dari berbagai pihak untuk ikut berperan aktif dalam usaha mencapai mutu pendidikan yang optimal.

Kenyataannya, pembelajaran di Sekolah Dasar masih belum dilaksanakan secara optimal khususnya mata pelajaran Matematika SD. Keterlibatan siswa dalam pembelajaran masih terbatas pada penerimaan materi yang disampaikan dengan model pembelajaran konvensional yang kurang inovatif yaitu pendekatan saintifik, hal ini akan berdampak pada hasil belajar siswa.

Berdasarkan hasil observasi yang dilaksanakan di SD Gugus I Gusti Ngurah Rai dalam proses pembelajaran terutama menyangkut bidang Matematika masih banyak kelemahan dilihat dari hasil belajar Matematika yang masih dibawah kkm dan nilai kkm di Gugus I Gusti Ngurah Rai adalah 70. SD Negeri 3 Padangsambian terdapat 31 siswa yang nilainya masih kurang dari kkm. SD Negeri 5 Padangsambian terdapat 24 siswa yang nilainya masih kurang dari kkm. SD Negeri 6 Padangsambian terdapat 25 siswa yang nilainya masih kurang dari kkm. SD Negeri 11 Padangsambian terdapat 43 siswa yang nilainya masih kurang dari kkm. SD Negeri 17 Padangsambian terdapat 24 siswa yang nilainya masih kurang dari kkm. SD Negeri 18 Padangsambian terdapat 23 siswa yang nilainya masih kurang dari kkm. Jumlah siswa di SD Gugus I Gusti Ngurah Rai berjumlah 404 dan nilai yang masih kurang dari kkm berjumlah 170 siswa. Data ini didapat dari hasil observasi yang diberikan oleh masing masing guru kelas V di SD Gugus I Gusti Ngurah Rai. Berdasarkan observasi di lapangan pada hari Selasa tanggal 11 Februari 2019, hal itu disebabkan karena guru menerapkan pembelajaran hanya berdasarkan buku pegangan yang membuat siswa kurang tertarik terhadap pembelajaran Matematika karena terkesan kurang kreatif. Pembelajaran Matematika yang terlaksana menekankan pada siswa untuk mengingat, menghafal, dan mengerjakan tugas di buku pegangan sehingga siswa kesulitan dalam memecahkan masalah dan mengaplikasikan pengetahuan Matematika. Secara tidak langsung pola pembelajaran seperti itu akan membuat hasil belajar siswa menjadi tidak optimal.

Berkaitan dengan kenyataan tersebut, alangkah baiknya dalam pembelajaran diusahakan menggunakan pembelajaran yang inovatif dan menyenangkan seperti model pembelajaran kooperatif, dalam pembelajaran kooperatif terdapat berbagai model atau tipe-tipe yang lebih spesifik guna guru lebih leluasa dalam merancang pembelajaran dikelas agar lebih bervariasi. Salah satunya adalah model pembelajaran Tipe Numbered Head Together. Model pembelajaran tipe Numbered Head Together merupakan salah satu tipe pembelajaran kooperatif yang menekankan pada struktur khusus yang 
dirancang untuk mempengaruhi pola interaksi siswa dan memiliki tujuan untuk meningkatkan hasil belajar siswa.

Permasalahan seperti paparan tersebut, akan dilakukan penelitian tentang Pengaruh Model Pembelajaran Kooperatif Learning Tipe Numbered Head Together Terhadap Pengetahuan Matematika Kelas V SD Gugus I Gusti Ngurah Rai Tahun Ajaran 2018/2019. Secara umum, tujuan pembelajaran matematika di sekolah dasar adalah agar siswa mampu dan terampil menggunakan matematika.Selain itu juga, dengan pembelajaran matematika dapat memberikan tekanan penataran nalar dalam penerapan matematika. Menurut Depdiknas (2009:9). Kompetensi atau kemampuan umum pembelajaran matematika disekolah dasar adalah sebagai berikut:

Melakukan operasi hitung penjumlahan, pengurangan, perkalian, pembagian beserta operasi campurannya, termasuk yang melibatkan pecahan. Menentukan sifat dan unsur berbagai bangun datar dan bangun ruang sederhana, termasuk penggunaan sudut, keliling, luas, dan volume. Menentukan sifat simetri, kesebangunan, dan sistem koordinat. Menggunakan pengukuran: satuan, kesetaraan antarsatuan, dan penaksiran pengukuran. Menetukan dan menafsirkan data sederhana, seperti: ukuran tertinggi, terendah, rata-rata, modus, mengumpulkan, dan menyajikannya. Dan memecahkan masalah, melakukan penalaran, dan mengkomunikasikan gagasan secara matematika.

Matematika merupakan salah satu bidang studi yang ada pada semua jenjang pendidikan. mulai dan tingkat sekolah dasar hingga perguruan tinggi. Bahkan matematika diajarkan ditaman kanak-kanak secara inormal. Belajar matematika merupakan suatu syarat cukup untuk melanjutkan pendidikan kejenjang berikutnya. Karena dengan belajar matematika, kita akan belajar menalar secara kritis, kreatif dan aktif. Matematika merupakan ide-ide abstrak yang berisi simbul-simbul, maka konsep-konsep matematika harus dipahami terlebih dahulu sebelum memanipulasi simbul-simbul itu. Menurut Susanto (2013:184) Matematika merupakan salah satu disiplin ilmu yang dapat meningkatkan kemampuan berfikir dan beragumentasi memberikan kontribusi dalam penyelesaian masalah sehari-hari dan salam dunia kerja, serta memberikan dukungan dalam pengembangan ilmu pengetahuan dan teknologi. Kebutuhan akan aplikasi matematika saat ini dan masa depan tidak hanya untuk keperluan sehari-hari, tetapi terutama dalam dunia kerja dan untuk mendukung perkembangan ilmu pengetahuan. Direktorat Pembinaan Sekolah dasar (dalam Ariyanto, 2015:2) menyatakan Matematika merupakan ilmu universal yang mendasari perkembangan teknologi modern mempunyai peran penting dalam berbagai disiplin, dan memajukan daya pikir manusia. Oleh karena itu, matematika sebagai ilmu dasar perlu dikuasai dengan baik oleh siswa terutama sejak usia sekolah dasar.

Kompetensi dapat dikatakan kemampuan yang ada pada diri siswa untuk menunjukkan dan mengaplikasikan keterampilan tersebut di dalam kehidupan sehari-hari. Kompetensi inti mencakup tiga ranah yaitu, ranah kompetensi sikap, ranah kompetensi keterampilan, dan ranah kompetensi pengetahuan. Namun dalam kurikulum 2013, kompetensi sikap dijabarkan lagi menjadi dua macam agar lebih operasional yaitu dengan istilah sikap spiritual dan sikap sosial. Kompetensi adalah pengetahuan, keterampilan, dan nilai dasar yang merefleksikan dalam kebiasaan berpikir dan bertindak (Kosasih, 2014:13). UU No. 20 tahun 2013 menyatakan tentang Sistem Pendidikan didefinisikan pula bahwa kopetensi (lulusan) merupakan kualifikasi kemampuan lulusan yang mencakup sikap, pengetahuan, dan keterampilan, yang akan menjadi acuan bagi pengembangan kurikulum dalam rangka mewujudkan tujuan pendidikan Nasional. Sehingga dapat dirangkum bahwa, kompetensi pengetahuan matematika adalah peningkatan berbagai kemampuan peserta didik dalam mata pelajaran matematika yang diperoleh melalui hasil tes setelah melaksanakan proses pembelajaran. Kompetensi yang dimaksud menyangkut aspek spiritual, sikap, pengetahuan, keterampilan yang di dalamnya termasuk fisik dan mental peserta didik. Kompetensi pengetahuan matematika adalah kemampuan yang dimiliki oleh siswa pada kegiatan pembelajaran matematika yang diperoleh melalui proses pembelajaran .

Menurut Rusman (2012:202) Pembelajaran kooperatif adalah bentuk pembelajaran dengan cara siswa belajar dan bekerja dalam kelompok - kelompok kecil secara kolaboratif yang anggotanya terdiri dari empat sampai enam orang dengan struktur kelompok yang bersifat heterogen.

Model Pembelajaran Numbered Head Together adalah suatu model pembelajaran yang lebih mengedepankan kepada aktivitas siswa dalam mencari, mengolah, dan melaporkan informasi dari berbagai sumber yang akhirnya dipresentasikan di depan kelas (Rahayu, 2006). Menurut Mulyana (2016) dengan pembelajaran kooperatif tipe NHT ini akan membuat siswa tidak jenuh dalam kegiatan pembelajaran dan siswa dapat sharing dengan temantemannya untuk memecahkan permasalahan yang diberikan oleh guru, karena guru hanya sebagai fasilitator untuk mengembangkan pengetahuan siswa, serta mampu membuat siswa mampu bertanggung jawab lebih baik lagi yang pada akhirnya akan meningkatkan hasil belajar siswa menjadi lebih baik. Menurut Anwar (2018) Model pembelajaran Numbered Head Together merupakan salah satu bentuk pembelajaran yang berpusat pada siswa dan mendorong inkuiri terbuka dan berfikir bebas, membantu untuk menjadi pembelajar mandiri yang dapat 
memecahkan masalah. Penggunaan model ini bertujuan untuk memberikan kesempatan kepada siswa untuk saling membagikan ide-ide dan mempertimbangkan jawaban yang paling tepat. Model Numbered Head Together adalah bagian dari model pembelajaran kooperatif struktural, yang menekankan pada struktur-struktur khusus yang dirancang untuk mempengaruhi pola interaksi siswa. Model pembelajaran ini memilik ciri khas dimana guru hanya menunjuk seorang siswa untuk mewakili kelompoknya tanpa memberitahu terlebih dahulu siapa yang akan mewakili kelompoknya tersebut. Sehingga cara ini menjamin keterlibatan total semua siswa. Cara ini upaya yang sangat baik untuk meningkatkan tanggung jawab individual dalam diskusi kelompok. Menurut Musdalifa (2015) pengetian Numbered Heads Together (NHT) adalah model pembelajaran yang membagi siswa ke dalam beberapa kelompok kecil, hal ini ditujukan agar siswa dapat saling bekerjasama, saling membantu dan saling memotivasi dengan siswa lainnya, agar siswa dapat mencapai hasil yang maksimal dari pembelajaran tersebut. Model pembelajaran kooperatif learning tipe Numbered Head Together adalah model pembelajaran yang membentuk kelompok heterogen, setiap kelompok beranggotakan 3-5 siswa dan setiap anggota memiliki satu nomor. Kemudian guru mengajukan pertanyaan untuk didiskusikan bersama dalam kelompok dengan menunjuk salah satu nomor untuk mewakili kelompok. Adapun kelebihan Model Pembelajaran Numbered Head Together ; (1) Dapat meningkatkan prestasi belajar siswa, (2) Mampu memperdalam pemahaman siswa, (3) Melatih tanggung jawab siswa, (4) Menyenangkan siswa dalam belajar, (5) Mengembangkan rasa ingin tahu siswa, (5) Meningkatkan rasa percaya diri siswa, (6) Setiap siswa termotivasi untuk menguasai materi

Adapun tujuan penelitian ini adalah sebagai berikut: 1) Untuk mengetahui pengetahuam Matematika kelompok yang dibelajarkan melalui model pembelajaran Kooperatif Learning Tipe Numbered Head Together Kelas V SD Gugus I Gusti Ngurah Rai Denpasar Tahun Ajaran 2018/2019, 2) Untuk mengetahui pengetahuan Matematika kelompok yang dibelajarkan melalui pembelajaran konvensiaonal Kelas V SD Gugus I Gusti Ngurah Rai Denpasar Tahun Ajaran 2018/2019, dan 3) Untuk mengetahui pengaruh yang signifikan model Pembelajaran Kooperatif Learning Tipe Numbered Head Together Terhadap Pengetahuan Matematika Kelas V SD Gugus I Gusti Ngurah Rai Denpasar Tahun Ajaran 2018/2019

\section{Metode}

Pelaksanaan penelitian dilakukan di SD Gugus I Gusti Ngurah Rai Denpasar Barat, Provinsi Bali. SD Negeri 17 Padangsambian, Jalan Tangkuban Perahu No. 10 Denpasar Barat (kelompok eksperimen) dan di SD Negeri 18 Padangsambian, Jalan Gunung Lumut Denpasar Barat (kelompok kontrol).

Waktu penelitian dilaksanakan mulai bulan 11 Februari 2019 sampai dengan 23 Februari 2019 pada semester II (dua) atau semester genap Tahun Ajaran 2018/2019. Perlakuan yang diberikan sebanyak 6 kali di kelompok eksperimen dan di kelompok kontrol tidak dilakukan instrumensasi. Jumlah perlakuan yang diberikan telah disesuikan dengan jam pelajaran terkait materi dalam penelitian ini yang telah diatur dalam kurikulum dan silabus.

Pelaksanaan penelitian ini terdiri dan tiga tahapan yaitu, tahap persiapan penelitian, tahap pelaksanaan penelitian, dan tahap akhir penelitian. Adapun uraian dari setiap tahapan sebagai berikut:

1. Tahap Persiapan Penelitian

Pada tahapan persiapan eksperimen ini, kegiatan yang dilakukan oleh peneliti yaitu: (1) Melakukan wawancara dengan kepala sekolah di Gugus I Gusti Ngurah Rai dan beberapa wali kelas V di masing-masing sekolah Negeri di Gugus I Gusti Ngurah Rai untuk mengetahui ada atau tidaknya kelas unggulan di SD Negeri yang ada di Gugus I Gusti Ngurah Rai, (2) Mempersiapkan kurikulum dan menyusun silabus bersama wali yang terkait dengan materi yang akan diuji cobakan dalam penelitian ini, (3) Menyusun RPP (Rencana Pelaksanaan Pembelajaran) beserta LKS, (4) Mempersiapkan pembelajaran kooperatif tipe Numbered Head Together terhadap pengetahuan matematika yang akan digunakan untuk membelajarkan kelas eksperimen, (5) Mengonsultasikan instrumen penelitian pre-test dan post-test bersama wali kelas dan dosen pembimbing, (6) Mengonsultasikan RPP, LKS dan media pembelajaran bersama wali kelas dan dosen pembimbing, (7) Mengadakan uji coba instrumen penelitian soal pre-test, (8) Melakukan pengundian untuk menentukan sampel, (9) Memberikan pre-tes kepada sampel untuk membuktikan kesetaraan kelompok, (10) Analisis data pre-tes sampel dengan teknik matching.

2. Tahap Pelaksanaan Penelitian

Saat pelaksanaan eksperimen kegiatan yang ditempuh yaitu: (1) Memberikan perlakuan pada kelas eksperimen berupa model pembelajaran kooperatif Learning tipe Numbered Head Together terhadap Pengetahuan Matematika, (2) Memberikan perlakuan pada kelas kontrol berupa pembelajaran pendekatan saintifik, (3) Perlakuan diberikan sebanyak 6 kali di kelas eksperimen dan 6 kali juga di kelas kontrol. Jumlah perlakuan yang diberikan telah disesuaikan dengan jam pelajaran terkait materi dalam 
penelitian ini yang telah diatur dalam kurikulum dan silabus, (4) Memberikan post-tes pada akhir penelitian baik untuk kelompok eksperimen maupun kontrol.

3. Tahap Akhir Penelitian

Saat tahap akhir penelitian kegiatan yang ditempuh yaitu: (1) Menganalisis data hasil penelitian,

(2) Melakukan uji hipotesis.

Penelitian ini dilaksanakan di kelas V SD Gugus I Gusti Ngurah Rai Kecamatan Denpasar Utara pada semester II tahun ajaran 2018/2019. Rancangan penelitian yang digunakan dalam penelitian ini adalah penelitian kuantitatif dengan desain eksperimental yaitu: quasi eksperiment (eksperimen semu). Desain ini memiliki kelompok kontrol, tetapi tidak bisa sepenuhnya mengontrol variabel-variabel luar yang mempengaruhi pelaksanaan eksperimen (Sugiyono, 2014). Hal ini dikarenakan kemampuan peneliti dalam mengamati perilaku siswa sangat terbatas terutama ketika siswa berada di luar sekolah (rumah), peneliti juga tidak memiliki kemampuan untuk mengetahui persepsi siswa terhadap perlakuan secara pasti. Desain eksperimen yang digunakan adalah nonequzvalent control group design."

\begin{tabular}{|c|c|c|}
\hline $\mathrm{O}_{1}$ & $\mathrm{x}$ & $\mathrm{O}_{2}$ (eksperimen) \\
\hline $\mathrm{O}_{3}$ & $\mathrm{x}$ & $\mathrm{O}_{4}$ (kontrol) \\
\hline
\end{tabular}

(Setyosari, 2015:211)

Gambar 1. Rancangan Penelitian Nonequivalent Control Group Design

Keterangan:

$\mathrm{O}_{1}: \quad$ Pre-test pada kelompok eksperimen.

$\mathrm{O}_{2}$ : Post-test pada kelompok eksperimen.

$\mathrm{x}$ : Perlakuan dengan menggunakan model pembelajaran kooperatif lerning tipe Numbered Head Together terhadap pengetahuan matematika untuk kelas eksperimen.

$\mathrm{O}_{3}$ : $\quad$ Pre-test pada kelompok kontrol.

$\mathrm{O}_{4}$ : $\quad$ Post-test pada kelompok kontrol.

Pelaksanaan penelitian ini terdiri dan tiga tahapan yaitu, tahap persiapan penelitian, tahap pelaksanaan penelitian, dan tahap akhir penelitian. Adapun uraian dari setiap tahapan sebagai berikut:

Salah satu bagian dalam langkah-langkah penelitian adalah menentukan populasi dan sampel penelitian. Menurut Sugiyono (2014 : 11) Populasi adalah "wilayah keseluruhan generalisasi yang terdiri atas objek atau subjek yang mempunyai kualitas dan karakteristik tertentu yang ditetapkan oleh peneliti untuk dipelajari dan kemudian ditarik kesimpulannya". Setyosari (2015:221) menyatakan populasi merupakan "keseluruhan dari objek, orang, peristiwa, atau sejenisnya yang menjadi perhatian dan kajian dalam penelitian."

Jadi dapat disimpulkan bahwa populasi adalah keseluruhan dari objek, orang, peristiwa, atau sejenisnya yang berjumlah lebih besar dan biasanya dipakai untuk menggeneralisasikan hasil penelitian. Populasi dalam penelitian ini adalah siswa kelas V di SD Negeri yang terdapat pada Gugus I Gusti Ngurah Rai tahun pelajaran 2018/2019 yang berjumlah 404 siswa. Data selengkapnya disajikan pada Tabel 01 berikut.

Tabel 1. Komposisi Populasi Kelas V SD Negeri Gugus I Gusti Ngurah Rai

\begin{tabular}{lccc}
\hline \multicolumn{1}{c}{ Nama Sekolah } & \multicolumn{2}{c}{ Kelas } & Jumlah Siswa Keseluruhan \\
\hline SD N 3 Padang Sambian & VA 32 & VB 31 & 77 \\
SD N 5 Padang Sambian & VA 33 & VB 32 & 78 \\
SD N 6 Padang Sambian & VA35 & VB35 & 76 \\
SD N 11 Padang Sambian & VA38 & VB37 VC37 & 112 \\
SD N 17 Padang Sambian & V31 & & 38 \\
\hline
\end{tabular}




\begin{tabular}{ccc}
\hline SD N 18 Padang Sambian & VA31 & VB32 \\
\hline Jumlah & & $\mathbf{4 0 4}$ \\
\hline & & (Sumber: Wali Kelas V setiap SD)
\end{tabular}

Pemilihan sampel penelitian ini tidak dilakukannya pengacakan individu, karena tidak bisa mengubah kelas yang telah terbentuk sebelumnya. Kelas yang dipilih sesuai dengan kelas yang ada di sekolah dan tidak dilakukannya pengacakan individu, kemungkinan pengaruh-pengaruh dari keadaan subjek mengetahui dirinya dilibatkan dalam eksperimen dapat dikurangi sehingga penelitian ini benarbenar menggambarkan pengaruh perlakuan yang diberikan.

Berdasarkan hasil random, diperoleh dua sekolah sebagai sampel yaitu kelas V SD Negeri 17 Padangsambian sebanyak 31 siswa dan kelas V SD Negeri 18 Padangsambian sebanyak 31 siswa. Setelah itu akan melakukan penyetaraan sampel. Kemudian dilanjutkan dengan menentukan kelas eksperimen dan kelas kontrol dengan memberikan pre-test dengan jumlah soal sebanyak 40. Dari hasil pre-test, Kelas V SD Negeri 17 Padangsambian, Jalan Tangkuban Perahu No. 10 Denpasar Barat (kelompok eksperimen) dan Kelas V SD Negeri 18 Padangsambian, Jalan Gunung Lumut Denpasar Barat (kelompok kontrol).

Metode pengumpulan data adalah cara yang digunakan untuk mengumpulkan data. Darmadi (2014:40) menyatakan metode pengumpulan data adalah cara-cara yang dapat digunakan oleh peneliti untuk mengumpulkan data. Data yang dikumpulkan dalam penelitian ini adalah data Pengetahuan Matematika Kelas V SD Gugus I Gusti Ngurah Rai Denpasar Tahun Ajaran 2018/2019. Teknik pengumpulan data ada dua yaitu dengan teknik tes dan teknik non tes. Dalam penelitian ini, metode pengumpulan data yang digunakan adalah metode tes. Tes adalah alat atau prosedur yang dipergunakan dalam rangka pengukuran dan penilaian (Sudijono. 2013:66). Menurut Mardapi (2012:108) Tes merupakan salah satu bentuk instrumen yang digunakan untuk melakukan pengukuran. Jadi, metode tes pada hakikatnya merupakan cara pengumpulan data dengan memberikan beberapa pertanyaan atau tugas yang semuanya harus dikerjakan atau dijawab oleh peserta, dan hasil dari tes berupa skor.

Dalam penelitian ini data yang dianalisis adalah data pengetahuan Matematika siswa, untuk mendapatkan data tersebut digunakan tes pada ranah kognitif untuk mengukur pengetahuan Matematika. Tes adalah alat atau prosedur yang dipergunakan dalam rangka pengukuran dan penilaian (Sudijono, 2011). Untuk menilai dan mengukur pengetahuan Matematika yang berkenan dengan penguasaan bahan pengajaran sesuai dengan tujuan pendidikan dan pangajaran. Penyusunan tes pengetahuan yang baik merupakan tugas guru yang menantang. Dikatakan demikian sebab tes yang berkualitas tidak dengan sendirinya terjadi, melainkan perlu persiapan yang matang. Persiapan tersebut diawali dengan penyusunan kisi-kisi tes. Penyusunan kisi-kisi akan memberikan bantuan untuk menyiapkan tes sesuai dengan tujuan dan mewakili materi yang pernah diberikan dalam proses pendidikan (Yusuf, 2015).

Instrumen yang digunakan untuk mengumpulkan data tentang Pengetahuan Matematika adalah tes pengetahuan bentuk objektif tipe pilihan ganda biasa. Tes ini mengungkapkan tentang penguasaan siswa terhadap pengetahuan Matematika yang mereka peroleh di kelas V. Setiap soal disertai dengan empat alternatif jawaban yang dipilih siswa (alternatif a, b, c, dan d). Setiap item diberikan skor satu bila siswa menjawab dengan benar (jawaban dicocokkan dengan kunci jawaban). Serta skor nol untuk siswa yang menjawab salah. Skor yang diperoleh dari tes dapat diketahui dengan rumus, sebagai berikut:

$$
\text { Nilai }=\quad \text { Skor Mentah } \times 100
$$

Skor Maksimum Ideal (1)

(Sumber: Sudijono, 2011:318)

Sebuah tes dapat dikatakan baik sebagai alat pengukur apabila telah dilakukan uji validitas dan realibilitas. Sebelum tes diuji cobakan, terlebih dahulu dikonsultasikan dengan guru kelas serta dosen pembimbing, lalu kemudian dilakukan uji validitas, uji daya beda, uji tingkat kesukaran dan uji reliabilitas.

Statistik inferensial adalah "suatu cara yang digunakan untuk data sampel, dan hasilnya akan digeneralisasikan untuk populasi dimana sampel diambil" (Sugiyono, 2013:23). Teknik analisis data yang dilakukan adalah sebagai berikut.

a. Uji Prasyarat Analisis

Sebelum dilakukan uji hipotesis terlebih dahulu dilakukan uji prasyarat analisis sebagai berikut.

b. Uji Normalitas

Untuk mengetahui sebaran data skor pengetahuan Matematika siswa masing-masing kelompok berdistribusi normal atau tidak, digunakan uji Kolmogorov-Smirnov dengan rumus: 


$$
\mathrm{KS}=\max (|s i-p i|, s i-1-p i \mid)
$$

(Sumber: Mairing, 2017: 139)

Keterangan:

$I \quad=$ indeks untuk $\mathrm{xi}$, dengan $\mathrm{i}=1,2,3, \ldots, \mathrm{m}$

$X_{i}=$ data berbeda ke-i yang telah diurutkan dari terkecik ke terbesar

$m$ = banyak data yang berbeda $\underline{F i}$

$S_{i}=n$

$F_{i}=$ frekuensi kumulatif $\mathrm{ke}-\mathrm{i}$

$n$ = banyak data

$p_{i}=\mathrm{p}(\mathrm{Z}<\mathrm{zi})$ (luas daerah di bawah kurva normal baku di sebelah kiri $\left.\mathrm{zi}\right)$

Kriteria pengujian adalah jika KShitung $<$ KStabel maka sebaran data berdistribusi normal, sedangkan jika KShitung $\geq$ KStabel maka sebaran data tidak berdistribusi normal. Taraf signifikansinya adalah 5\% (Mairing, 2017).

c. Uji Homogenitas

Uji Homogenitas dilakukan untuk rnenunjukkan bahwa perbedaan yang terjadi pada uji hipotesis benar-benar terjadi akibat adanya perbedaan varians antar kelompok, bukan sebagai akibat perbedaan dalam kelompok. Uji homogenitas dapat dilakukan apabila kelompok data tersebut berdistiibtist normal. Uji homogenitas varians dilakukan dengan uji F rumusnya sebagai berikut:

$$
\mathrm{F}=\frac{\text { varian terbesar }\left(\mathrm{s}_{1}^{2}\right)}{\text { varian terkecil }\left(\mathrm{s}_{2}^{2}\right)}
$$

(Sugiyono, 2013: 140)

Keterangan:

$\left(\mathrm{s}_{1}^{2}\right)=$ Varians terbesar
$\left(\mathrm{s}_{1}^{2}\right)=$ Varians terbesar

Kriteria pengujian, jika $F_{\text {hit }} \leq F_{\text {tabel }}$ Maka sampel homogen. Pengujian dilakukan pada taraf signifikan 5\% dengan derajat kebebasan unluk pembilang $n_{1}-1$ dan derajat kebebasan untuk penyebut $\mathrm{n}_{2}-1$.

Hipotesis dalam penelitian ini adalah:

$\mathrm{H}_{0} \quad$ Tidak terdapat perbedaan yang signifikan pengetahuan Matematika antara kelompok siswa yang dibelajarkan menggunakan Model Pembelajaraan Kooperatif Learning tipe Numbered Head Togeher dan kelompok siswa yang dibelajarkan menggunakan pembelajaran konvensional kelas V SD Gugus I Gusti Ngurah Rai Denpasar Tahun Ajaran 2018/2019.

Hipotesis Statistik yang diuji dalam penelitian ini adalah:

$$
\mathrm{H}_{0}: \mu_{1}=\mu_{2}
$$

Koyan, (2012:34)

Keterangan :

$\mu_{1}$ : rata-rata pengetahuan kelompok siswa yang mengikuti pembelajaran dengan menggunakan model kooperatif tipe Numbered Head Together terhadap Pengetahuan Matematika

$\mu_{2}$ : rata-rata kompetensi pengetahuan kelompok siswa yang tidak mengikuti pembelajaran dengan model kooperatif tipe Numbered Head Together terhadap Pengetahuan Matematika

Jika data yang diperoleh sudah memenuhi prasyarat uji normalitas dan homogenitas maka analisis yang digunakan adalah statistik parametrik. Analisis statistik yang digunakan untuk menguji hipotesis penelitian ini adalah uji beda mean (uji t). Uji Hipotesis menggunakan uji-t dengan rumus 
separated varians. Rumus uji-t dengan rumus separated varians digunakan bila jumlah anggota sampel sama $\eta_{1}=\eta_{2}$ dan varians homogen.

\section{Hasil dan Pembahasan}

Uji normalitas sebaran data dilakukan pada kedua kelompok data yang meliputi data kelompok eksperimen dan data kelompok kontrol. Hal ini dilakukan untuk mengetahui sebaran data gain skor ternormalisasi pengetahuan Matematika yang akan digunakan dalam pengujian hipotesis. Uji normalitas sebaran data dilakukan dengan menggunakan uji Kolmogorov-Smirnov dengan rumus KS $=\max (|s i-p i|$, $s i-1-p i \mid)$ dan ketentuan harga KShitung yang diperoleh dibandingkan dengan harga KStabel dengan taraf signifikansi $5 \%=0,218$

Berikut diuraikan mengenai hasil pengujian normalitas yaitu (1) uji normalitas sebaran data kelompok eksperimen, (2) uji normalitas sebaran data kelompok kontrol.

1. Uji normalitas sebaran data kelompok eksperimen diperoleh KShitung $=\max (|s i-p i|, s i-1-p i \mid)=$ 0,177 , sedangkan pada taraf signifikansi $5 \%$ diperoleh KStabel $=0,218$. Dengan demikian dapat diperoleh perbandingan KShitung dengan KStabel ialah KShitung $=0,177<$ KStabel $=0,218$. Berdasarkan hasil analisis uji normalitas sebarann data pada kelompok eksperimen dapat disimpulkan bahwa sebaran data pengetahuan Matematika pada kelompok eksperimen berdistribusi normal.

2. Uji normalitas sebaran data kelompok kontrol diperoleh KShitung $=\max (|s i-p i|, s i-1-p i \mid)=0,131$, sedangkan pada taraf signifikansi 5\% diperoleh $\mathrm{KStabel}=0,218$. Dengan demikian dapat diperoleh perbandingan KShitung dengan KStabel ialah KShitung = 0,131 < KStabel $=0,218$. Berdasarkan hasil analisis uji normalitas sebaran data pada kelompok kontrol dapat disimpulkan bahwa sebaran data pengetahuan Matematika pada kelompok kontrol berdistribusi normal.

Berdasarkan analisis uji normalitas data, di bawah ini disajikan ringkasan hasil uji normalitas untuk kelompok eksperimen dan kelompok control dalam tabel 02 berikut.

\begin{tabular}{lcccc}
\hline No & Sampel & KS hitung & KS table & Keterangan \\
\hline 1 & Kelompok Eksperimen & 0,177 & 0,218 & Berdistribusi Normal \\
2 & Kelompok Kontrol & 0,131 & 0,218 & Berdistribusi Normal \\
\hline
\end{tabular}

Tabel 2. Hasil Uji Normalitas Kelompok Ekspermen dan Kelompok Kontrol

Setelah dilakukan uji normalitas sebaran data selanjutnya dilakukan uji normalitas varians dengan Uji Fisher (Uji-F). Kriteria pengujian jika Fhitung $<$ Ftabel maka data homogen namun jika Fhitung $>$ Ftabel, maka data tidak homogen. Pengujian dilakukan pada taraf signifikansi 5\% dengan derajat kebebasan untuk pembilang $n 1-1=(31-1=30)$ dan derajat kebebasan untuk penyebut $n 2-1=(31-1=30)$. Hasil uji homogenitas dapat disajikan dalam Table 3 berikut.

Tabel 3. Hasil Uji Homogenitas Varians Kelompok Eksperimen dan Kelompok Kontrol

\begin{tabular}{llccc}
\hline \multicolumn{1}{c}{ Sampel } & Varians & Fhitung & Ftabel & Kesimpulan \\
\hline Kelompok Eksperimen & 0,034 & \multirow{2}{*}{1,48} & 1,84 & Homogen \\
Kelompok Kontrol & 0,023 & & & \\
\hline
\end{tabular}

Tabel 4. Hasil Analisis Uji-t Data Pengetahuan Matematika

\begin{tabular}{lcccccccc}
\hline \multicolumn{1}{c}{ No } & Kelompok Sampel & & $\mathbf{N}$ & Dk & & $\boldsymbol{X}$ & thitung & ttabel \\
\hline 1 & Eksperimen & 31 & & & 0,434 & & & \\
2 & Kontrol & 31 & 60 & 0,270 & 3,97 & 2,000 \\
\hline
\end{tabular}

Berdasarkan hasil analisis diperoleh thitung $=3,97$. Pada taraf signifikansi $5 \%$ dan dk $=31+31-2=$ 60 diperoleh ttabel $=2,000$. Oleh karena itu thitung $=3,97>$ ttabel $=2,000$ maka $\mathrm{H} 0$ ditolak. Hal ini berarti terdapat pengaruh model pembelajaran Kooperatif Learning Tipe Numbered Head Together terhadap pengetahuan Matematika kelas V SD Gugus I Gusti Ngurah Rai Tahun Pelajaran 2018/2019. 
Berdasarkan hasil analisis data kompetensi pengetahuan Matematika diperoleh rata- rata gain skor kompetensi pengetahuan Matematika pada kedua kelompok yaitu pada:

Pengetahuan Matematika pada kelompok eksperimen diperoleh nilai rata-rata gain skor ternormalisasi yaitu 0,434. Rata-rata gain skor ternormalisasi pengetahuan Matematika kelompok eksperimen tersebut kemudian dibandingkan dengan menggunakan interpretasi $n$-gain, sehingga dapat diketahui pengetahuan Matematika siswa kelompok eksperimen berada pada kriteria sedang. Pengetahuan Matematika pada kelompok kontrol diperoleh nilai rata-rata gain skor ternormalisasi yaitu 0,270. Rata-rata gain skor ternormalisasi pengetahuan Matematika kelompok kontrol tersebut kemudian dibandingkan dengan menggunakan interpretasi n-gain, sehingga dapat diketahui pengetahuan Matematika kelompok kontrol berada pada kriteria rendah.

Dari hasil analisis diketahui bahwa sebaran data gain skor kompetensi pengetahuan Matematika siswa berdistibusi normal dan memiliki varians yang homogen.

Berdasarkan uji hipotesis diperoleh thitung $=3,97$ sedangkan ttabel dengan $\mathrm{dk}=31+31-2=60 \mathrm{dan}$ taraf signifikansi $5 \%$ diperoleh nilai ttabel $=2,000$ sehingga thitung $=3,97>$ ttabel $=2,000$ maka Ho diterima. Hal ini berarti terdapat pengaruh model pembelajaran Kooperatif Learning Tipe Numbered Head Together terhadap pengetahuan Matematika kelas V SD Gugus I Gusti Ngurah Rai Tahun Ajaran $2018 / 2019$.

Kelompok eksperimen diberikan perlakuan berupa model pembelajaran Kooperatif Learning Tipe Numbered Head Together terhadap pengetahuan Matematika memiliki nilai rata-rata lebih tinggi dibandingkan dengan kelompok kontrol. Hal ini disebabkan karena model pembelajaran Kooperatif Learning Tipe Numbered Head Together terhadap pengetahuan Matematika menekankan pada partisipasi dan aktivitas siswa untuk mencari sendiri segala sesuatu mengenai materi pelajaran yang akan dipelajari. Siswa terlibat langsung dan aktif dalam proses pembelajaran mulai dari perencanaan, menentukan topik yang akan dipelajari, melakukan investigasi, serta menyiapkan dan menyajikan laporan. Hal tersebut memiliki dampak positif dalam meningkatkan motivasi dan prestasi belajar siswa. Penyampaian bahan ajar secara interaktif dapat mempermudah pembelajaran karena didukung oleh beberapa aspek seperti teks, gambar, audio, video, dan animasi sehingga pembelajaran akan lebih menarik serta siswa lebih mudah dalam memahami materi yang disampaikan. Dilanjutkan dengan kegiatan investigasi yang menekankan inisiatif siswa, dibuktikan dengan pertanyaan-pertanyaan yang siswa ajukan, dengan sumber- sumber yang mereka temukan. Setelah melakukan kegiatan investigasi, setiap kelompok menyiapkan dan menyajikan laporan. Hal tersebut melatih siswa untuk memiliki kemampuan yang baik dalam berkomunikasi maupun dalam keterampilan proses kelompok.

\section{Simpulan dan Saran}

Berdasarkan hasil pembahasan dan analisis terdapat perbedaan yang signifikan kompetensi pengetahuan matematika kelompok yang dibelajarkan menggunakan Model Pembelajaran Kooperatif Learning Tipe Numbered Head Together dan kelompok yang dibelajaran menggunakan model pembelajaran konvensional Kelas V SD Gugus I Gusti Ngurah Rai Tahun Ajaran 2018/2019. Hal ini dibuktikan dengan hasil perhitungan uji-t diperoleh thitung= 3,97 dengan taraf signifikansi $5 \%$ dan $\mathrm{dk}=60$ diperoleh nilai ttabel $=2,000$. Serta rata-rata gain skor ternormalisasi pengetahuan Matematika kelompok eksperimen $X 1=0,434>X 2=0,270$ rata-rata gain skor ternormalisasi pengetahuan Matematika kelompok kontrol. Dengan demikian dapat disimpulkan model terdapat pengaruh yang signifikan kompetensi pengetahuan matematika kelompok yang dibelajarkan menggunakan model pembelajaran kooperatif learning tipe Numbered Head Together dan kelompok yang dibelajarkan dengan pembelajaran konvensional kelas V SD Gugus I Gusti Ngurah Rai Denpasar tahun ajaran 2018/2019.

\section{Daftar Rujukan}

Agung, Gede. 2011. Pengantar Evaluasi Pendidkkan. Singaraja: STKIP Singaraja.

Agung, Gede. 2014. Metodologi Penelitian Pendidikan. Singaraja: STKIP Singaraja.

Anwar, Khoirudin, Tri Ari Sasongko, Sri Adi Widodo. 2018. Pengaruh Model Pembelajaran Kooperatif Tipe Numbered Heads Together (NHT) terhadap Prestasi Belajar Matematika Siswa. Prosiding Seminar Nasional Etnomatnesia Hal. 790-794. Tersedia Pada: http://jurnal.ustjogja.ac.id/index.php/etnomatnesia/article/view/2419/1380.

Arikunto, Suharsimi. 2012. Dasar-Dasar Evaluasi Pendidikan. Jakarta: Bumi Aksara. 
Dantes, Nyoman. 2017. Desain Eksperimen dan Analisis Data. Depok: PT. Rajagrafindo Persada.

Darmadi, Hamid. 2014. MetodePemlitian Pendidikandan Sosial. Bandung: Alfabeta.

Kosasih. 2014. Strategi Belajar dan Pembelajaran Implementasi Kurikulum 2013. Bandung: YramaWidya.

Koyan, I Wayan. 2012. Statistik Pendidikan: Teknik Analisis Data Kuantitatif. Singaraja: Universitas Pendidikan Ganesha Pers.

Kurniasih dan Sani.2015. Ragam Pengembangan Model Pembelajaran. Jakarta: Kata Pena.

Marhadi, Hendri. 2014. Penerapan Model Pembelajaran Kooperatif Tipe Numbered Heads Together (NHT) untuk Meningkatkan Hasil Belajar Siswa Kelas Vd SDN 184 Pekanbaru. Jurnal Primary Program Studi Pendidikan Guru Sekolah Dasar Fakultas Keguruan dan Ilmu Pendidikan Universitas Riau | $\begin{array}{llllll}\text { Volume } & 3 & \text { Nomor } & 2 \text {, Hal. } & \text { 73-81. } & \text { Tersedia }\end{array}$ https://ejournal.unri.ac.id/index.php/JPFKIP/article/view/2497.

Mulyana, Mutia Agisni, Nurdinah Hanifah, Asep Kurnia Jayadinata. 2016. Penerapan Model Kooperatif Tipe Numbered Heads Together (NHT) Untuk Meningkatkan Hasil Belajar Siswa Pada Materi Kenampakan Alam Dan Sosial Budaya. Hal. 331-340. Tersedia Pada: http://ejournal.upi.edu/index.php/penailmiah/article/view/3039.

Musdalifa, Naella Ichdatul, Murtono, Ika Oktavianti. 2015. Peningkatan Hasil Belajar IPS Melalui Model Kooperatif Tipe NHT Siswa Kelas V SDN 5 Ngembalrejo. Jurnal Ilmiah Kependidikan Vol. 5 No. 1 Hal. 1-16. Tersedia Pada: https://jurnal.umk.ac.id/index.php/RE/article/view/444/475.

Sani, Ridwan Abdullah. 2014. Pembelajaran Saintifik untuk Implementasi Kurikulum 2013. Jakarta: PT Bumi Aksara.

Setyosari, Punaji. 2015. Metpde Pengembangan Pendidikan dan Pengembangan. Jakarta: Kencana Prenada Media Group.

Sudijono, Anas. 2013. PengantarEvaluasiPendidikan. Jakarta: Rajawali Pers.

Sugiyono. 2015. Statistika Untuk Penelitian. Bandung: Alfabeta.

Sugiyono, 2011. Metode Penelitian Pendidikan: Pendekatan Kuantitatif, Kualitatif, dan R\&D. Bandung: Alfabeta.

Susanto, Ahmad. 2013. Teori Belajardan Pembelajaran, Jakarta :Kharisma Putra Utama.

Taniredja, dkk. 2015. Model-Model Pembelajaran Inovatif dan Efektif. Bandung: Alfabeta.

Trianto, 2011. Pengantar Penelitian Pendidikan Bagi Pengembangan Dan Profesi Pendidikan Dan Tenaga Kependidikan. Jakarta: Kencana.

Yusuf, Muri. 2015. Asesmendan Evahtasi Pendidikan. Jakarta: Prenadamedia Group. 